\title{
Penyimpanan Bakteri Escherichia coli Dan Streptococcus pneumonie Pada Media Cryoprotective Dengan Metode Freeze Drying
}

\author{
Yati Supriatin ${ }^{1)}$, Fitri Fadhilah ${ }^{2)}$,Vanessa Ayu Sumirat ${ }^{3)}$ \\ ${ }^{1}$ S1 Kimia Konsentrasi Analis Medis Sekolah Tinggi Analis Bakti Asih \\ Email: yatisupriatin@gmail.com \\ ${ }^{2}$ D3 Analis Kesehatan Sekolah Tinggi Analis Bakti Asih \\ Email:ailuvito@gmail.com \\ ${ }^{3}$ S1 Kimia Konsentrasi Analis Medis Sekolah Tinggi Analis Bakti Asih \\ Email: vanessasumirat@gmail.com
}

\begin{abstract}
APA Citation: Supriatin, Y., Fadhilah, F., \& Sumirat, V. A. (2020). Penyimpanan Bakteri Escherichia coli Dan Streptococcus pneumonie Pada Media Cryoprotective Dengan Metode Freeze Drying. Quagga: Jurnal Pendidikan dan Biologi, 12(1), 24-30. doi: 10.25134/quagga.v12i1.2148.
\end{abstract}

Received: 20-11-2019

Accepted: 11-01-2020

Published: 20-01-2020

\begin{abstract}
Abstrak: Proses perbanyakan dan penyimpanan bakteri menjadi hal yang harus diperhatikan karena cara penyimpanan sangat terkait dengan perubahan sifat bakteri yang disimpan. Di Laboratorium, kultur bakteri murni dipindahkan dengan metode subkultur. Kekurangan subkultur berulang adalah memakan waktu, beresiko kontaminasi dan mutasi genetik. Penelitian ini bertujuan untuk mengembangkan penyimpanan bakteri jangka panjang yang aplikatif di Laboratorium Mikrobiologi serta menentukan jenis Cryoprotectan Agent yang dapat mempertahankan viabilitas sel Escherichia coli dan Streptococcus pneumonie dengan metode Freeze Drying. Metode penelitian yang digunakan adalah eksperimen dengan menambahkan Skim Milk 10\% dan gliserol 10\% sebagai Cryoprotectan Agent pada pelet sel Escherichia coli dan Streptococcus pneumonie dengan metode Freeze Drying. Digunakan kontrol tanpa penambahan Cryoprotectan Agent dengan metode Freeze Drying dan kontrol tanpa penambahan Cryoprotectan Agent yang disimpan dalam refrigator (non Freeze Drying) kemudian jumlah koloni bakteri dihitung setelah masa simpan 2,4,6 minggu.Selanjutnya data yang diperoleh diolah secara statistik menggunakan metode statistik non parametrik kruskal wallis. Hasil penelitian menunjukkan bahwa Skim Milk 10\% maтри mempertahankan viabilitas Sel Escherichia coli dengan persentase penurunan viabilitas paling rendah yaitu 4,2\%, namun jenis Cryoprotectan agent metode Freeze Dry belum mampu mengawetkan dan mempertahankan viabilitas sel Streptococcus pneumonie.
\end{abstract}

Kata Kunci: Cryoprotectan Agent; Cell viability; Escherichia coli;, Streptococcus pneumonie; Freeze Drying.

\begin{abstract}
The process of multiplication and storage of bacteria into things to be considered because storage it is closely related to the change character of bacteria. At Laboratories, the pure bacteria culture are using subculture.The lack of the repeated subculture are consuming time, risk contamination and genetic mutations. This research concerning aims to develop applicative long-term storage of bacteria at Microbiology Laboratory and to know the type of Cryoprotectan Agent that can maintain viability cells of Escherichia coli and Streptococcus pneumonie using the Freeze Drying method.The method used was experiment method by added 10\% Skim Milk and 10\% glycerol as Cryoprotectan Agent on Escherichia coli and Streptococcus pneumonie cell using Freeze Drying method for control without added Cryoprotectant Agent using Freeze Drying method and without added Cryoprotectant Agent stroage in refrigator (non Freeze Drying) and then counting bacterial colony after 2,4,6 weeks saving time. The results showed that the $10 \%$ Milk Skim was able to maintain the viability of the lowest percentage of Escherichia coli cells which was $4.2 \%$, but the type of Cryoprotectan agent Freeze Dry method was not able to preserve and maintain the viability of S. pneumonie cells.
\end{abstract}

Keywords : Cryoprotectan Agent; Cell viability; Escherichia coli; Streptococcus pneumonie; Freeze Drying. 
Quagga: Jurnal Pendidikan dan Biologi

Volume 12, Nomor 1, Januari 2020, pp.24-30
p-ISSN 1907-3089, e-ISSN2651-5869

https://doi.org/10.25134/quagga.v12i1.2148

\section{PENDAHULUAN}

Bakteri merupakan organisme bersel satu, ada bakteri yang bersifat menguntungkan maupun merugikan bagi kehidupan manusia, namun demikian bakteri banyak memegang peranan penting dalam bidang kesehatan, industri makanan, lingkungan, dan lain sebagainya. Dalam bidang industri yang melibatkan kerja bakteri, proses perbanyakan dan penyimpanan bakteri menjadi hal yang harus diperhatikan karena sangat terkait dengan sifat bakteri tersebut dalam proses industri, begitupun dalam dunia kesehatan, proses perbanyakan dan penyimpanan bakteri sangat penting sehubungan dengan proses diagnos suatu penyakit yang disebabkan oleh bakteri. Proses perbanyakan dan penyimpanan bakteri memerlukan media yang berfungsi untuk menyediakan nutrisi bagi kelangsungan proses perbanyakan sel bakteri tersebut. Faktor-faktor yang harus diatur selama pertumbuhan bakteri adalah zat makanan, $\mathrm{pH}$, temperatur, aerasi, konsentrasi garam, pada media. Pembiakan bertujuan untuk mempertahankan strain bakteri hidup, agar terhindar dari terkontaminasi bakteri lain yang tidak diharapkan dan menghindari mutasi genetik sehingga memiliki sifat yang sama seperti pada isolat aslinya. Keberhasilan pembiakan tergantung pada prosedur pemilihan media dan usia kultur yang tepat saat pembiakan (Jawetz et al., 2014).

Bakteri setelah diisolasi dan tumbuh dalam media murni, sangat penting untuk dijaga viabilitas dan kemurniannya dengan menjaga agar kultur murni bebas dari kontaminasi. Biasanya di Laboratorium, kultur bakteri murni dipindahkan secara berkala ke media segar (subkultur) untuk memungkinkan pertumbuhan dan kelangsungan hidup bakteri yang berkelanjutan. Saat memindahkan bakteri harus dalam kondisi aseptik untuk menghindari kontaminasi. Kekurangan subkultur yang dilakukan berulang kali adalah memakan waktu serta akan menjadi sulit untuk mempertahankan sejumlah besar media murni dengan waktu yang lama. Selain itu, ada risiko perubahan genetik sekaligus kontaminasi. Karena itu, sekarang digantikan oleh beberapa metode modern yang tidak perlu sering disubkultur. Metode ini meliputi pendinginan, metode parafin, cryopreservation, dan liofilisasi (Freeze Drying) ( Acharya, 2010 ). Cappuccino \& Sharman (2014) menegaskan bahwa suhu yang rendah dapat memperlambat atau menghambat aktivitas enzim sehingga memperlambat atau menghambat metabolisme sel, dan akibatnya pertumbuhan sel juga diperlambat atau dihambat.

Para ilmuan tertarik pada Freeze Drying dimulai pada pergantian abad ke-20 yang dipublikasikan oleh Bordas dan d'Arsonval di French Academy of Sciences. Setelah publikasi tersebut, kemudian Altman dan Gersh menggunakan teknik ini untuk menyiapkan sampel kering yang tidak terdistorsi untuk mikroskopi. Ronald Greaves, di Cambridge, Inggris, memulai karyanya disepanjang tahun 1930an dengan mempersiapkan suspensi kering bakteri hidup (Shukla, 2011).

Criste A. et al. (2014) menyatakan bahwa di antara banyak metode yang digunakan untuk melestarikan bakteri, metode yang paling efektif dan tahan lama adalah Cryopreservation dan Lyophilization (Freeze Drying). Cryopreservation melibatkan penggunaan suhu yang sangat rendah untuk menjaga struktur dan jaringan sel tetap utuh.

Leslie S. et al.(1995) memaparkan bahwa Freeze Drying memiliki beberapa efek samping yang tidak diinginkan, seperti denaturasi protein yang sensitif dan penurunan viabilitas untuk banyak jenis sel. Untuk mencegah atau mengurangi efek samping ini, zat pelindung seperti Skim Milk, sukrosa, gliserol, dan dimetil sulfoksida (DMSO) biasanya ditambahkan pada sampel sebelum dilakukan Freeze Drying.

Pertama kali pada tahun 1913 Keith mengamati bahwa zat aditif, seperti gula, susu atau gliserol, dapat melindungi bakteri dari kematian sel setelah pembekuan berulang. Kemudian Cody et al. (2008) mengemukakan bahwa lebih dari $90 \%$ strain bakteri yang dibekukan dalam Skim Milk 10\% ditemukan kembali dan menghasilkan viabilitas yang jauh lebih lama setelah pencairan. Parveen Jamal et al pada tahun 2016 menyatakan bahwa waktu penyimpanan bakteri bertahan pada pendinginan standar adalah 1-2 tahun.

Peneliti sebelumnya Susilawati dan Purnomo (2016) menyatakan bahwa perlakuan 
simpan beku dalam Cryoprotectant $10 \%$ Skim Milk $10 \quad \%$ Gliserol dan 10\% DMSO memberikan jumlah koloni yang relatif bertambah untuk Escherichia coli, Staphylococcus aureus, Shigella flexneri dan Bacillus subtilis.

Escherichia coli merupakan bakteri Gram negatif yang dapat digunakan sebagai indikator air bersih. Streptococcus pneumonie, merupakan bakteri Gram positif yang menjadi penyebab pneumonia. Kedua jenis bakteri tersebut sangat sering digunakan untuk kepentingan praktikum di Laboratorium Mikrobiologi. Untuk kepentingan pendidikan analis khususnya di Sekolah Tinggi Analis Bakti Asih, penyimpanan bakteri-bakteri yang digunakan untuk keperluan praktikum mikrobiologi itu sangat diperlukan yang saat ini baru dilakukan penyimpanan yang sifatnya jangka pendek dengan berbagai kelemahan yang ditimbulkan, seperti adanya perubahan sifat bakteri ketika ditumbuhkan pada media sehingga dapat mengecoh hasil diagnos, misalnya kesalahan menentukan tersangka bakteri pada pengamatan praktikum.

Berdasarkan penelitian sebelumnya dan literatur tersebut penulis tertarik untuk mengembangkan penyimpanan bakteri jangka panjang (Long Term) yang aplikatif di Laboratorium Mikrobiologi Sekolah Tinggi Analis Bakti Asih Bandung dengan menambahkan Cryoprotectant Agent menggunakan metode Freeze Drying. Penulis menambahkan Skim Milk 10\% dan gliserol 10\% sebagai Cryoprotectant Agent pada kultur bakteri yang dibekukan dalam freezer selama 18 jam dan dibeku keringkan dengan metode Freeze Drying disimpan selama 2, 4, 6 minggu sebagai pendahuluan awal maka dari itu dipilihlah rentang waktu yang relatif pendek, lalu di uji viabilitas selnya setelah masa simpan yang dihitung jumlah koloni Escherichia coli menggunakan metode Pour Plate dan koloni Streptococcus pneumonie menggunakan metode Spread Plate.

\section{METODOLOGI PENELITIAN}

Penelitian ini bersifat eksperimen. Peneliti melakukan penelitian dengan menambahkan Skim Milk $10 \%$ dan gliserol 10\% pada pelet sel
Escherichia coli dan Streptococcus pneumonie sebagai Cryoprotectan Agent yang dibekukan dalam freezer selama 18 jam lalu dilakukan pengering bekuan dengan metode Freeze Drying kemudian disimpan pada refrigator pada suhu $4^{\circ} \mathrm{C}$ dan diuji viabilitas selnya setelah masa simpan 2,4,6 minggu dihitung jumlah koloni Escherichia coli menggunakan metode Pour Plate dan koloni Streptococcus pneumonie menggunakan metode Spread Plate (Kelompok Eksperimen). Dan tidak menambahkan Skim Milk 10\% dan gliserol 10\% pada pelet sel Escherichia coli dan Streptococcus pneumonie yang dibeku keringkan dengan metode Freeze Drying dan yang disimpan pada refrigator suhu $4^{\circ} \mathrm{C}$ dan diuji viabilitas selnya setelah masa simpan 2,4,6 minggu dihitung jumlah koloni Escherichia coli menggunakan metode Pour Plate dan koloni Streptococcus pneumonie menggunakan metode Spread Plate (Kelompok Kontrol).

Desain penelitian yang digunakan adalah perbandingan kelompok statis (Static Group Comparison yaitu membandingkan perlakuan pada kelompok kontrol dan eksperimen.

\section{HASIL DAN PEMBAHASAN}

Uji penelitian dilakukan dengan menginokulasi Escherichia coli dan Streptococcus pneumonie menggunakan Skim Milk $10 \%$ dan gliserol $10 \%$ sebagai Cryoprotectan Agent dengan tujuan menentukan jenis Cryprotectan Agent yang dapat mempertahankan viabilitas sel Escherichia coli dan Streptococcus pneumonie dengan metode Frezee Drying dan menentukan Cryoprotectant Agent yang menghasilkan persentase penurunan viabilitas paling stabil untuk sel Escherichia coli dan Streptococcus pneumonie dengan metode Frezee Drying setelah masa simpan 2,4 dan 6 minggu. 
Quagga: Jurnal Pendidikan dan Biologi

Volume 12, Nomor 1, Januari 2020, pp.24-30

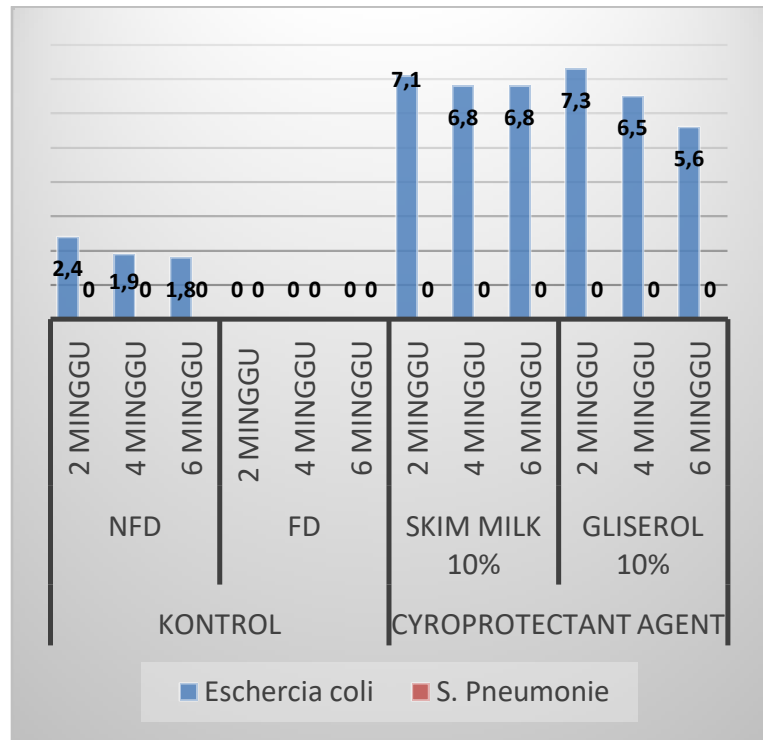

Gambar 1. Jumlah Koloni Bakteri Uji Setelah Masa Simpan 2,4,6 Minggu Dengan

Penambahan Skim Milk 10\% Dan Gliserol 10\% Menggunakan Metode Frezee Drying.

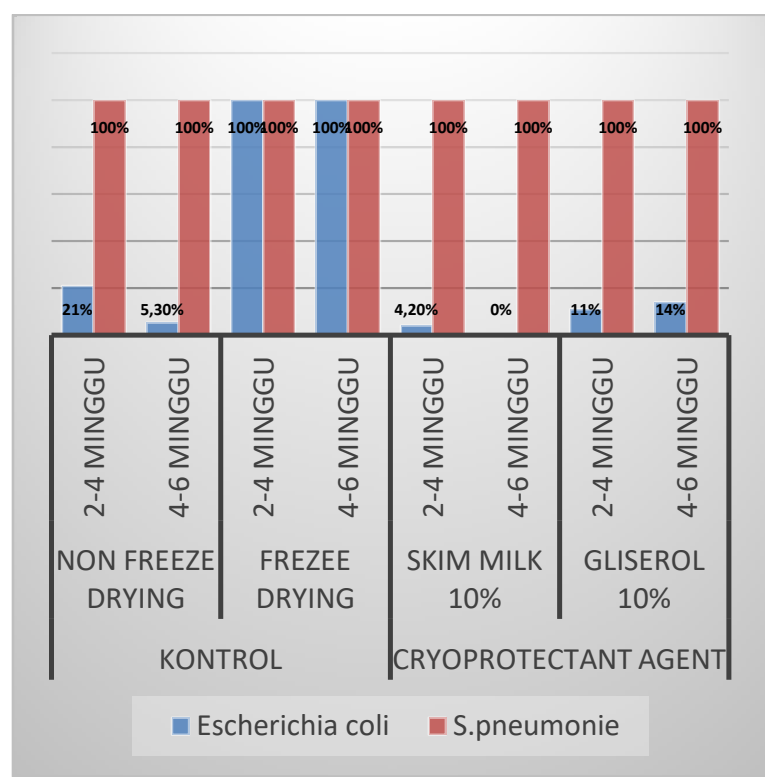

Gambar 2. Persentase Penurunan Jumlah Koloni Bakteri Uji

Pada hasil penelitian setelah masa simpan 2,4 dan 6 minggu pada penambahan Skim Milk $10 \%$ pada viabilitas Sel Escherichia coli didapatkan sedikit penurunan, didapatkan persentase penurunan jumlah koloni Escherichia coli $4 \%$ pada minggu ke 2 sampai minggu ke 4 dan $0 \%$ pada minggu ke 4 sampai minggu ke 6. Dan pada penambahan gliserol
p-ISSN 1907-3089, e-ISSN2651-5869

https://doi.org/10.25134/quagga.v12i1.2148

$10 \%$ didapatkan persentase penurunan jumlah koloni Escherichia coli $11 \%$ pada minggu ke 2 sampai minggu ke 4 dan 14\% pada minggu ke 4 sampai minggu ke 6 . Namun dengan penambahan Skim Milk $10 \%$ sebagai Cryoprotectant Agent lebih memberikan hasil penurunan yang stabil dari pada gliserol $10 \%$ hasil penelitian ini memberikan hasil yang sama dengan hasil penelitian yang dilakukan oleh Cody et al (2008) S. Kandil \& M. Soda (2015) Susilawati \& Purnomo (2016) bahwa penggunaan Skim Milk $10 \%$ dapat mempertahankan viabilitas sel Escherichia coli. Maka penggunaan Skim Milk 10\% sebagai Cryoprotectan Agent baik untuk mempertahankan viabilitas sel Escherichia coli.

Bakteri Gram negatif mempunyai lapisan peptidoglikan yang tipis sebagai konsekuensinya sel lebih peka terhadap perusakan fisik. Membran luarnya dikenali karena adanya lipopolisakarida yang tertanam di dalamnya yang merupakan komponen utama lembaran luar membran luar. Bagian lipopolisakarida bersifat antigenik. Bagian lipid tertanam di dalam membran (Jawetz et al., 2014). Menurut Carvalho et al (2004) dalam Skim Milk terkandung protein utama yaitu kasein. Saat ditambahkannya Skim Milk 10\% sebagai Cryoprotectant Agent gugus alkohol $\left(\mathrm{CH}_{2} \mathrm{OH}\right)$ pada peptidoglikan sel bakteri akan berikatan dengan ion karboksilat $(\mathrm{COOH})$ dari protein membentuk ester. Karena gugus alkohol beresonansi stabil maka akan kehilangan protonnya $($ atom $\mathrm{H})$, menyebabkan atom $\mathrm{H}$ berikatan dengan gugus hidroksil $(\mathrm{OH})$ dari karboksilat protein membentuk air $\left(\mathrm{H}_{2} \mathrm{O}\right)$. Reaksinya.

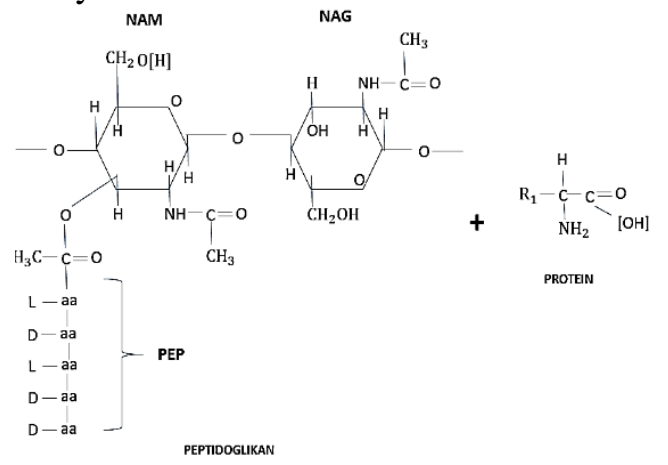

Gambar 3. Peptidoglikan Bakteri bereaksi dengan protein dari skim milk Sumber : (Jawetz et al,2014). 
Lapisan peptidoglikan terdiri dari suatu saringan polimerik berikatan silang. Bagian glikan adalah suatu polimer linier dari subunit monosakarida berselang seling : $\mathrm{N}$ asetilglukosamin (NAG) dan asam $\mathrm{N}$-asetil muramat (NAM). Polimer ini adalah suatu tulang punggung karbohidat saringan ini. Bagian peptido polimer adalah suatu benang tipis asam amino yang bekerja untuk mengikat silang serat polisakarida yang bersebelahan dengan subunit NAM, membentuk suatu jaringan dengan kekuatan peregangan tinggi (Jawetz et al., 2014).

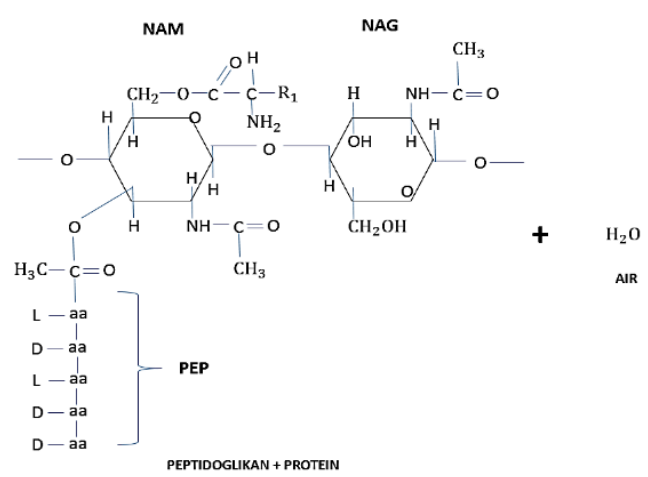

Gambar 4.Reaksi Peptidoglikan Bakteri dengan air Sumber : (Jawetz et al,2014).

Saat ditambahkannya Skim Milk 10\% sebagai Cryoprotectant Agent dimulai pembentukan selaput (coating) yang menyeluruh seperti kapsul yang menyebabkan kandungan asam lemak yang terdapat pada membran sel mengubah fluiditas membran (Carvalo et al., 2008) disebabkan juga adanya kalsium (Ca) pada protein yang berkontribusi terhadap enzim selular (Cody et al., 2008). Berdasarkan kemampuannya menembus membran sel Skim Milk tergolong pada Cryprotectan ekstraseluler yang mampu menstabilkan membran fosfolipid bilayer ketika sel terdehidrasi di suhu rendah. Ukurannya ( $\geq 350$ dalton) (Martin-Dejardin et al., 2013).Skim Milk menciptakan struktur berpori dalam produk kering yang dikeringkan dan mengandung (protein) yang menyediakan lapisan pelindung untuk sel (Abadias et al.,2001). Skim Milk sebagai zat pelindung dapat meningkatkan efek perlindungan intrinsiknya selama penyimpanan, sampai tingkat yang berbeda tergantung pada senyawa yang ditambahkan. Kemampuan senyawa untuk mempertahankan kelangsungan hidup sel selama periode pengeringan terlibat dengan adanya kelompok amino, kelompok alkohol sekunder atau keduanya (Fontde Valdez et al., 1983).

Hasil uji viabilitas S.pneumonie menunjukkan tidak ada pertumbuhan setelah masa penyimpanan 2,4,6 minggu baik pada penambahan Cryoprotectan Gliserol $10 \%$ maupun pada Skim Milk 10\% metode Freeze dry dan control. Hal ini berkaitan dengan virulensi yang dimiliki S.pnemoniae, virulensi yang dimiliki S.pnemoniae berasal dari kapsulnya yang mempunyai sifat antifagosit. Diketahui kapsul S.penemoniae mencegah terjadinya pengikatan imuoglobulin iC3b dan Fc yang terdapat di permukaan sel bakteri dengan reseptor. Selain kapsul, protein pnemolysin yang dimiliki S.pnemoniae berpotensi menjadikannya bersifat virulen. Pnemolysin diproduksi selama fase log. (Mitchell, 2010).

S. pnemoniae bersifat fastidious sehingga diperlukan media yang sesuai dengan pertumbuhannya. S. pnemoniae tumbuh dengan baik pada media Agar Darah karena dalam pertumbuhannya membutuhkan sumber katalase yaitu darah dan di kondisikan dalam $5 \% \mathrm{CO}_{2}$ (Ranjan, 2014). Pada proses kultur $S$. pnemoniae terjadi metabolisme pembentukan autolysin yang menyebabkan terjadinya penurunan jumlah sel dan hilangnya viabilitas sel (Beatriz., et.al. 2017). Maka diperlukan pemilihan media yang tepat untuk menumbuhkan S.pnemoniae. Pada penelitian ini digunakan Agar Darah sebagai media pertumbuhan S.pnemoniae, diketahui bahwa penambahan Tris-HCL pada media Todd-Hewit yang mengandung $2 \%$ ragi dapat meningkatkan pertumbuhan $S$. pnemoniae pada waktu 6 jam setelah diinkubasi (Alegre, 2015). Hal ini menunjukkan bahwa penggunaan Agar Darah sebagai media pertumbuhan tidaklah cukup untuk mempertahankan pertumbuhan S.pnemoniae dengan optimal. Kemudian factor kontaminasi sangat mungkin terjadi pada penyimpanan waktu yang lama mengingat $S$. pnemoniae bersifat fastidious (Wasas, et al. 1998). 
Hal lain yang perlu diperhatikan adalah sifat S.pnemoniae yang sulit di tumbuhkan pada media dan hanya dapat bertahan 2 sampai 3 hari pada media jika berhasil di tumbuhkan (Siberry G., et al., 2001). Selain itu mempertimbangkan penggunaan metode freeze drying pada $S$. pnemoniae yang menyebabkan terjadinya sel kehilangan daya osmotic dan viabilitasnya karena terjadi kerusakan pada membrane sel disebabkan terjadinya pembekuan pada bagian eksraselular sel dan kristalisasi (Selwal K, et al. 2011). Hal ini menyebabkan terjadinya penurunan viabilitas sel secara drastic meskipun digunakan metode freeze drying.. Diketahui pula pada penambahan gliserol dan Skim milk sebagai Cryoprotectant pada $S$. pnemoniae yang telah di beku keringkan mengalami penurunan yang signifikan setelah 2 dan 4 minggu waktu penyimpanan (Siberry G., et al., 2001).

Artinya pengawetan sel S.pneumonie lebih sulit dibandingkan dengan Escherichia coli, selain rentan terhadap kontaminasi, juga sifatnya yang lebih cenderung bersifat anaerobic fakultatif dapat lebih optimal pertumbuhannya dengan menambahkan perlakuan khusus yaitu dengan menambahkan karbondioksida 5\% (Soedarto,2014).

Jika ditinjau dari struktur dinding sel nya S.pneumonie terdiri dari enam lapis yang terdiri dari peptidoglycan dengan teichoic acid yang melekat pada $N$-acetylmuramc acid. Pada membrane sel melekat lipoteichoic acid yang identic dengan teichoic acid dan keduanya mengandung phoshorylcholine yang merupakan elemen penting pada biologi S.pneumonie karena choline ini spesifik melekat pada Choline binding reseptor yang selalu terdapat pada sel manusia. Perlu kajian ilmiah yang lebih mendalam lagi apakah keberadaan choline ini juga yang menentukan tidak dapat bertahannya sel S.pneumonie pada pengawetan metode Freeze Drying walaupun menggunakan Cryoptrotectant Agent.

\section{SIMPULAN}

Penambahan Skim Milk 10\% dan gliserol $10 \%$ sebagai Cryoprotectan Agent dapat mempertahankan viabilitas sel Escherichia coli dengan persentase penurunan yang paling rendah 4,2\% terjadi pada viabilitas sel Escherichia coli dengan penambahan Skim Milk 10\% dengan metode Frezee Drying, namun kedua jenis Croprotectan agent belum mampu mempertahankan viabilitas sel Streptococcus pneumonie untuk semua waktu penyimpanan.

\section{UCAPAN TERIMA KASIH}

Ucapan terimakasih kami sampaikan kepada :

1. Kemenristekdikti yang telah membiayai penelitian ini dalam hibah Penelitian Dosen Pemula (PDP) 2018,

2. Bapak Suryatmana Tanuwidjaya,Drs.M.Si selaku Ketua StaBa atas support nya

3. Ibu Selvi Septianasari selaku asisten Lab biologi yang telah menyiapkan segala keperluan bahan dan alat lab

4. Ine Febri Zulfitri atas bantuannya selama pengerjaan penelitian di laboratorium Biologi.

\section{REFERENSI}

A.M. Mitchell, T.J. Mitchell. 2010.Streptococcus pneumoniae: virulence factors and variation, Clinical Microbiology and Infection, Volume 16, Issue 5, Pages 411-418

Abadias et al. 2001. Effect of freeze-drying and protectants on viability of the biocontrol yeast Candida sake. International Journal of Food Microbiology. (65): 173-182.

Acharya, Tankeshwar. 2010. Maintenance and Preservation of Pure Cultures of BacteriaI.

[Online].Tersedia:http://microbeonline.c $\mathrm{om} /$ maintenance-andpreservation-ofpure-cultures-of-bacteria. [15/06/2017].

Alegre, Santiago V, Isabel Fernández-Natal, Eduardo López-Fidalgo, Octavio Miguel Rivero-Lezcano. 2015. Preparation of inocula for experimental infection of blood with Streptococcus pneumoniae, MethodsX, Volume 2, Pages 463-468.

Beatriz Quintero Moreno, María Araque, and Evelyn Mendoza. 2017. "Evaluation of Two Supplemented Culture Media for Long-Term, Room-Temperature Preservation of Streptococcus pneumoniae Strains," BioMed Research International, vol. 2017, Article ID 
Quagga: Jurnal Pendidikan dan Biologi

Volume 12, Nomor 1, Januari 2020, pp.24-30
p-ISSN 1907-3089, e-ISSN2651-5869

https://doi.org/10.25134/quagga.v12i1.2148
1218798, pages. https://doi.org/10.1155/2017/1218 798.

Cappuccino \& Sherman. 2014. Manual Labortaorium Mikrobiologi. Jakarta : EGC.

Carvalho et al. 2004. Relevant Factors For The Preparation of Freeze-Dried Lactic Acid Bacteria. International Journal. (14) : $835-847$.

Cody et al. 2008. Skim Milk Enhances the Preservation of Thawed $-80^{\circ} \mathrm{C}$ Bacterial Stocks. J Microbiol Methods Vol. 75(1) : 135-138.

Criste A. et al. 2014. Research Concerning Use of Long-Term Preservation Technique for Microorganism. Scientific Papers: Animal Science and Biotecnologies Vol. 47(2) : 400372.

Jawetz, Melnick \& Adelberg. 2014. Mikrobiologi Kedokteran Edisi ke 25. Jakarta : EGC.

Leslie S. et al. 1995. Trehalose and Sucrose Protect Both Membranes and Proteins in Intact Bacteria during Drying. Applied and Environtmental, Microbiology Vol. 61(10) : 0099-2240.

Martin-Dejardin et al. 2013. A Way To Follow The Viability On Encapsulated Bifidobacterium Bifidium Subjected To A Freeze - Drying Process In Target The Colon : Interest Of Flow Cytometry. Microbiology Review Vol.13(3): 470511.

Parveen Jamal et al. 2016. Bacterial Preservation for Short and Long-term Stroage. Experimental Methods in Modern Biotechnology. Vol. 2 (12):103.

Ranjan, S., Bakthavathsalam, G., Raghavan, V. V., \& Sindhu, R. K. 2014. Growth of Streptococcus pneumoniae on Macconkey Agar: Possibility of Impossible?. Journal of clinical and diagnostic research : JCDR, 8(12), DL01.doi:10.7860/JCDR/2014/10882.53 28
S. Kandil \& M. El Soda. 2015. Influence of Frezee Drying on Intracellular Enzymatic Activity and Autolytic Properties of Some Lactic Acid Bacterial Strain. Advances in Microbiology (5) : 371-382.

Selwal, Krishan \& K. Selwal, Manjit \& Gandhi, D.N.. (2011). Effect of freeze drying process on some properties of Streptococcus thermophilus isolated from dairy products. Brazilian Journal of Microbiology. 42. 10.1590/S151783822011000400037.

Shukla, S. 2011. Freeze Drying Process : A Review Article. International Journal of Pharmaceutical Sciences and Research Vol. 2 (12) : 3061-3068.

Siberry, G., Brahmadathan, K. N., Pandian, R., Lalitha, M. K., Steinhoff, M. C., \& John, T. J. (2001). Comparison of different culture media and storage temperatures for the long-term preservation of Streptococcus pneumoniae in the tropics. Bulletin of the World Health Organization, 79(1), 43-47.

Susilawati \& Purnomo. 2016. Viabilitas Sel Bakteri Dengan Cryoprotectant Agent Berbeda (Sebagai Acuan Dalam Preservasi Culture Collection di Laboratorium Mikrobiologi). Biogenesis Jurnal Ilmiah Biologi Vol. 4 (1) : 23021616.

Wasas, Avril D. Robin E. Huebner, Mignon De Blanche, Keith P. Klugman. 1998. Long-Term Survival of Streptococcus pneumoniae at Room Temperature on Dorset Egg Medium Journal of Clinical Microbiology, 36 (4) 1139-1140. 